\title{
Effects of Thinning Intensities on Soil Infiltration and Water Storage Capacity in a Chinese Pine-Oak Mixed Forest
}

\author{
Lili Chen, ${ }^{1,2}$ Zhiyou Yuan, ${ }^{1}$ Hongbo Shao, ${ }^{1,3}$ Dexiang Wang, ${ }^{2}$ and Xingmin $\mathrm{Mu}^{1,2}$ \\ ${ }^{1}$ Institute of Soil and Water Conservation, Chinese Academy of Science and Ministry of Water Resources, \\ Yangling, Shaanxi 712100, China \\ ${ }^{2}$ Northwest A\&F University, Yangling, Shaanxi 712100, China \\ ${ }^{3}$ Key Laboratory of Coastal Biology \& Bioresources Utilization, Yantai Institute of Coastal Zone Research (YIC), \\ Chinese Academy of Sciences (CAS), Yantai 264003, China \\ Correspondence should be addressed to Dexiang Wang; wangy@126.com and Xingmin Mu; xmmu@ms.iswc.ac.cn
}

Received 10 March 2014; Accepted 27 March 2014; Published 23 April 2014

Academic Editor: Xu Gang

Copyright (C) 2014 Lili Chen et al. This is an open access article distributed under the Creative Commons Attribution License, which permits unrestricted use, distribution, and reproduction in any medium, provided the original work is properly cited.

\begin{abstract}
Thinning is a crucial practice in the forest ecosystem management. The soil infiltration rate and water storage capacity of pine-oak mixed forest under three different thinning intensity treatments (15\%, 30\%, and 60\%) were studied in Qinling Mountains of China. The thinning operations had a significant influence on soil infiltration rate and water storage capacity. The soil infiltration rate and water storage capacity in different thinning treatments followed the order of control (nonthinning): $<60 \%,<15 \%$, and $<30 \%$. It demonstrated that thinning operation with $30 \%$ intensity can substantially improve soil infiltration rate and water storage capacity of pine-oak mixed forest in Qinling Mountains. The soil initial infiltration rate, stable infiltration rate, and average infiltration rate in thinning $30 \%$ treatment were significantly increased by $21.1 \%, 104.6 \%$, and $60.9 \%$, compared with the control. The soil maximal water storage capacity and noncapillary water storage capacity in thinning $30 \%$ treatment were significantly improved by $20.1 \%$ and $34.3 \%$ in contrast to the control. The soil infiltration rate and water storage capacity were significantly higher in the surface layer $(0 \sim 20 \mathrm{~cm})$ than in the deep layers $(20 \sim 40 \mathrm{~cm}$ and $40 \sim 60 \mathrm{~cm})$. We found that the soil property was closely related to soil infiltration rate and water storage capacity.
\end{abstract}

\section{Introduction}

Recently, the shortage of water resources and the deterioration of water quality have already become important issues in the world $[1,2]$. The forest ecosystem plays a significant role in water conservation and water quality improvement and the forest soil is a main carrier of water conservation $[3,4]$. Additionally, the soil infiltration rate and water storage capacity are important hydrological parameters in reflecting the soil and water conversation function of forest vegetation [5]. Although a lot of research on soil infiltration and storage capacity of different vegetation in different spatial scales has been performed [6-8], few studies have been done on soil infiltration rate and water storage capacity of pine-oak mixed forest in the Qinling Mountains of China.

The Qinling Mountains play an important role in the physical geographical pattern of China since it is a natural boundary between semihumid monsoon climate of warm temperate zone and humid climate of northern sun-tropical zone. Furthermore, the Qinling Mountains have an irreplaceable role in the ecological service function due to their rich natural geographical conditions. Thus, they gain great attention from scientists and government [9]. The pine-oak mixed forest is composed of Pinus tabulaeformis and Quercus aliena var. accuteserra. It belongs to a kind of significant water conservation forest and distributes widely in the middle Qinling Mountains. However, due to the lack of density management these years, the soil quality and stand growth of pine-oak mixed forest gradually degenerate and decline. Inevitably, the soil water conservation function is seriously affected.

Thinning is a crucial practice in the forest ecosystem management $[10,11]$. It has significant influence on forest soil, tree growth, and even the whole forest ecosystem $[12,13]$. 
Most research on thinning mainly has been concentrated on its effects on tree growth laws and stand volume [1416]. In recent years, the effect of thinning on forest soil has gradually become a hot issue [17-21]. A better understanding of thinning effects on forest soil is helpful to provide more strategies for the scientific management of pine-oak mixed forest and the construction of water conservation forestry in the Qinling Mountains. The present study is conducted in the pine-oak mixed forest 3 years after thinning in the Qinling Mountains. The main objectives are (1) to compare the soil infiltration rates and water storage capacities of three different thinning intensities $(15 \%, 30 \%$, and $60 \%)$ and (2) to identify the appropriate thinning intensity of pine-oak mixed forest which has the best function of soil water conservation.

\section{Study Area and Methods}

2.1. Study Area and Species. The study was carried out in Huoditang area $\left(33^{\circ} 25^{\prime} \sim 33^{\circ} 29^{\prime} \mathrm{N}, 108^{\circ} 25^{\prime} \sim 108^{\circ} 30^{\prime} \mathrm{E}\right.$, and $1300-$ $1800 \mathrm{~m}$ above the sea) at Qinling Mountains, Ningshan county of Shaanxi province (Figure 1). The climate belongs to the moist mountain climate of warm temperate zone, with an annual mean temperature of $9^{\circ} \mathrm{C}$. Mean annual precipitation is $1100 \mathrm{~mm}$ with July to September being the wettest period. Mean annual evaporation is $875 \mathrm{~mm}$. Total annual sunshine hours are $1100 \sim 1300 \mathrm{~h}$. The soil types in the study area are burozem (Chinese classification) and Hapli-Udic Cambosols under the US soil taxonomy classification system. The pineoak mixed forest belongs to a kind of typical vegetation type in this area. The dominant arbor species include Quercus aliena var. accuteserra and Pinus tabulaeformis. The dominant shrubs include Rubus corchorifolius, Lespedeza bicolor, and Elaeagnus pungens and the dominant herbs include Thalictrum aquilegifolium, Carex distachya, and Agropyron cristatum.

2.2. Plots Setting and Soil Sampling. The pine-oak mixed forest in the study area belongs to natural secondary and middle-aged forest which has been well protected since the 1970 s. In May 2009, a fixed plot of approximately $0.5 \mathrm{hm}^{2}$ was set up for the plot investigation in the study area. The thinning intensities in the fixed plot were $15 \%, 30 \%$, and $60 \%$, and a control (no thinning processing) group as well. Each thinning intensity treatment included 3 standard plots $(20 \times$ $20 \mathrm{~m}^{2}$ ). In August 2012, the basic characteristics of standard plots were investigated (Tables 1 and 2). In each standard plot, the soil samples were, respectively, collected from three layers $(0 \sim 20 \mathrm{~cm}, 20 \sim 40 \mathrm{~cm}$, and $40 \sim 60 \mathrm{~cm})$ in each soil profile, and there were 3 soil profiles along a diagonal direction. The collected soil samples were quickly taken back to the lab for testing the soil infiltration rate, soil water storage capacity, and soil properties. Each test was repeated three times.

2.3. Determination of Soil Infiltration Rate. Soil infiltration rate was determined using the double cutting ring infiltrometer [22]. The stable infiltration rate was the infiltration amount when it tended to be stable in a unit time. The initial infiltration rate $\left(V_{i}, \mathrm{~mm} \mathrm{~min}^{-1}\right)$ and the average infiltration

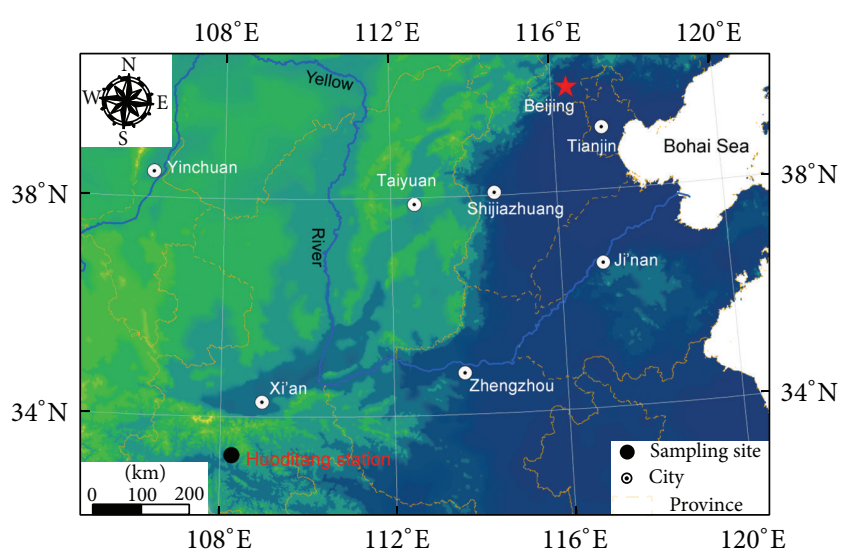

FIGURE 1: Location of the Huoditang area at Qinling Mountains in Ningshan county of Shaanxi province.

rate $\left(V_{a}, \mathrm{~mm} \mathrm{~min}^{-1}\right)$ were calculated as follows: (1) $V_{i}=L_{i} / T_{i}$; (2) $V_{a}=L_{a} / T_{a}$, where $L_{i}(\mathrm{~mm})$ is the infiltration amount in initial infiltration time and $T_{i}(\mathrm{~min})$ is the initial infiltration time. $L_{a}(\mathrm{~mm})$ is the total infiltration amount after reaching stability and $T_{a}(\mathrm{~min})$ is the stable infiltration time.

2.4. Calculation of Soil Water Storage Capacity. Soil water storage capacity is an important index to evaluate the soil water conservation ability. The soil maximal water storage capacity $\left(W_{t}, \mathrm{thm}^{-2}\right)$ and noncapillary water storage capacity $\left(W_{a}, \mathrm{thm}^{-2}\right)$ were derived from the following equations [23]: (1) $W_{t}=10000 P_{t} h$; (2) $W_{a}=10000 P_{a} h$, where $P_{t}$ (\%) indicates the total porosity of soil, $P_{a}(\%)$ indicates the noncapillary porosity of soil, and $h(\mathrm{~m})$ indicates the depth of soil layer.

2.5. Determination of Soil Physical Properties, Organic Matter, Microbial Quantities, and Enzyme Activities. Soil bulk density and porosity were determined as described by Picchio et al. [11]. Natural water content was measured using incubator $\left(85^{\circ} \mathrm{C}\right)$. Soil $\mathrm{pH}$ was analyzed by the $\mathrm{ZD}-2$ type potentiometric titration meter. The content of organic matter was determined as described by Nelson and Sommers [24]. Soil microbial quantities were calculated using the dilution plating method [25]. The catalase activity, dehydrogenase activity, urease activity, and invertase activity were measured, respectively, as described by Johnson and Temple [26], Margesin et al. [27], Nannipieri et al. [28], and Frankenberger and Johanson [29].

2.6. Statistical Analysis. Experimental data were analyzed using SPSS 18.0 (SPSS Inc., Chicago, IL, USA). One-way analysis of variance (one-way ANOVA) was employed to test the differences in soil infiltration rate and water storage capacity among various soil layers and thinning intensities. Duncan's test ( $\alpha=0.05$ ) was performed to determine the differences among means within ANOVA. Pearson's correlation analysis was performed to determine the correlation among soil infiltration rates, water storage capacities, and soil factors. Data in tables of this paper are the mean \pm standard error. 
TABLE 1: Stand characteristics of the standard plots.

\begin{tabular}{lccccc}
\hline Thinning intensity & $\begin{array}{c}\text { Stand density } \\
\left(\text { trees } \mathrm{hm}^{-2}\right)\end{array}$ & Species & $\begin{array}{c}\text { Average DBH } \\
(\mathrm{cm})\end{array}$ & \multicolumn{2}{c}{$\begin{array}{c}\text { Average height } \\
(\mathrm{m})\end{array}$} \\
\hline CK & 2100 & I/II & 24.97 & 18.50 & $\begin{array}{c}\text { Canopy density } \\
(\%)\end{array}$ \\
$15 \%$ & 1800 & I/II & 26.87 & 18.47 & 0.76 \\
$30 \%$ & 1500 & I/II & 28.17 & 18.77 & 0.77 \\
$60 \%$ & 900 & I/II & 25.80 & 18.70 \\
\hline
\end{tabular}

I: P. tabulaeformis; II: Q. aliena var. accuteserra.

TABLE 2: General status of soil profiles.

\begin{tabular}{lcccc}
\hline Sampling depth $(\mathrm{cm})$ & Color & Texture & Tightness & Humidity \\
\hline $0 \sim 20$ & Black-brown & Light loam & Loose & Moist \\
$20 \sim 40$ & Brown & Medium/heavy loam & Moderate & Moist \\
$40 \sim 60$ & Yellow-brown & Clay & Relatively compact & Slightly moist \\
\hline
\end{tabular}

\section{Results}

3.1. Soil Property Changes after Thinning. The soil properties changed dramatically after thinning (Table 3). The lowest soil bulk density $\left(1.17 \mathrm{~g} \mathrm{~cm}^{-3}\right)$ was found in thinning intensity of $30 \%$. In addition, the highest soil total porosity, noncapillary porosity, organic matter content, microbial quantities (bacteria, actinomyces, and fungus), and enzyme activities (catalase, dehydrogenase, urease, and invertase) were also found in thinning intensity of $30 \%$, while the soil $\mathrm{pH}$ had no obvious change under different thinning intensities.

3.2. Thinning Effects on Soil Infiltration Rate. Appropriate thinning significantly improved the soil infiltration rate. In pine-oak mixed forest, the soil infiltration rate firstly increased with the increase of stand density but then decreased after arriving at a certain extent (Figure 2). The soil initial infiltration rate, stable infiltration rate, and average infiltration rate of different thinning intensities increased in the same order of control (nonthinning): $<60 \%<15 \%$ $<30 \%$. The soil initial infiltration rate, stable infiltration rate, and average infiltration rate in thinning $30 \%$ and $15 \%$ were significantly different $(P<0.05)$ from the control but in thinning $60 \%$ had no significant difference $(P>0.05)$ from the control. Compared with the control, the soil initial infiltration rate, stable infiltration rate, and average infiltration rate in thinning $30 \%$ were, respectively, increased by $21.1 \%$, $104.6 \%$, and $60.9 \%$ and in thinning $15 \%$ were, respectively, increased by $13.5 \%, 71.1 \%$, and $47.4 \%$. Additionally, the soil initial infiltration rate, stable infiltration rate, and average infiltration rate from three soil layers were, respectively, in a range of $24.43 \sim 44.38 \mathrm{~mm} \mathrm{~min}^{-1}, 1.76 \sim 38.37 \mathrm{~mm} \mathrm{~min}^{-1}$, and $4.76 \sim 42.97 \mathrm{~mm} \mathrm{~min}^{-1}$ and significantly decreased $(P<0.01)$ with the increase of soil depth (Table 4; Figure 2).

3.3. Thinning Effects on Soil Water Storage Capacity. The soil water storage capacity of pine-oak mixed forest could be increased significantly with appropriate thinning practices. The water storage capacity firstly increased with the increase of stand density but then decreased after reaching a certain

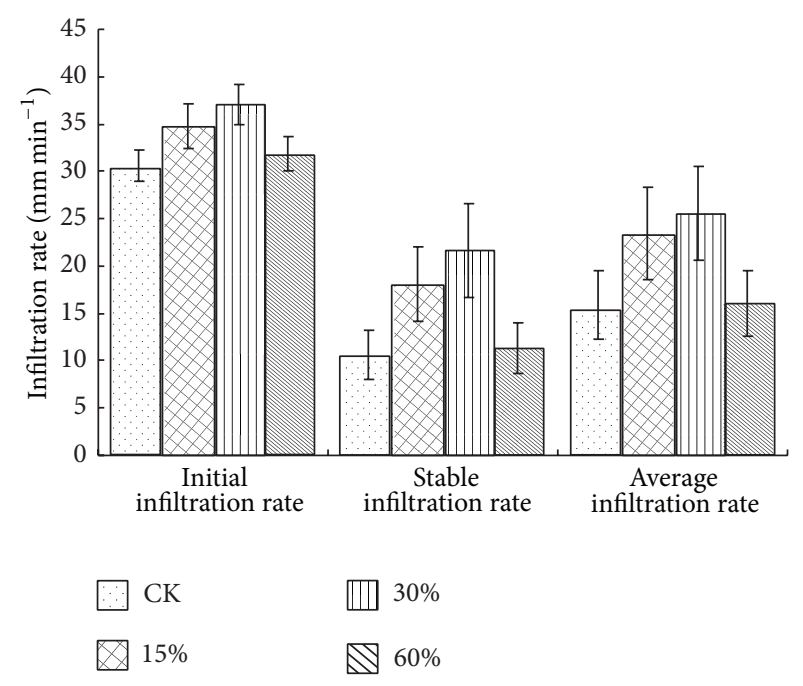

FIGURE 2: Soil infiltration rates of different thinning intensities.

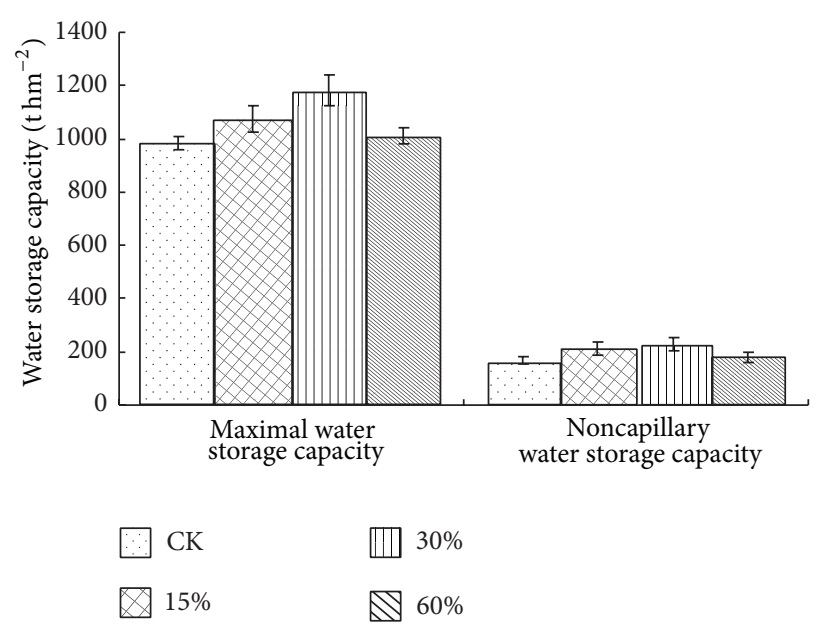

FIGURE 3: Soil water storage capacities of different thinning intensities. 
TABLE 3: Characteristics of forest soil properties.

\begin{tabular}{|c|c|c|c|c|}
\hline \multirow{2}{*}{ Index } & \multicolumn{4}{|c|}{ Thinning intensity } \\
\hline & $\mathrm{CK}$ & $15 \%$ & $30 \%$ & $60 \%$ \\
\hline Bulk density $\left(\mathrm{g} \mathrm{cm}^{-3}\right)$ & $1.24 \pm 0.00^{\mathrm{a}}$ & $1.20 \pm 0.01^{\mathrm{b}}$ & $1.17 \pm 0.01^{c}$ & $1.23 \pm 0.01^{\mathrm{a}}$ \\
\hline Total porosity (\%) & $49.20 \pm 0.80^{c}$ & $53.70 \pm 0.68^{\mathrm{b}}$ & $59.11 \pm 1.89^{\mathrm{a}}$ & $50.48 \pm 0.57^{\mathrm{bc}}$ \\
\hline Noncapillary porosity (\%) & $8.47 \pm 0.15^{\mathrm{b}}$ & $10.71 \pm 0.02^{\mathrm{a}}$ & $11.37 \pm 0.65^{\mathrm{a}}$ & $9.06 \pm 0.28^{\mathrm{b}}$ \\
\hline Natural water content $(\%)$ & $5.70 \pm 0.08^{c}$ & $10.08 \pm 0.44^{\mathrm{b}}$ & $10.63 \pm 0.76^{\mathrm{b}}$ & $12.86 \pm 0.39^{\mathrm{a}}$ \\
\hline $\mathrm{pH}$ & $6.47 \pm 0.03^{\mathrm{a}}$ & $6.53 \pm 0.03^{\mathrm{a}}$ & $6.40 \pm 0.12^{\mathrm{a}}$ & $6.53 \pm 0.09^{\mathrm{a}}$ \\
\hline Organic matter $\left(\mathrm{g} \mathrm{kg}^{-1}\right)$ & $17.11 \pm 1.60^{\mathrm{b}}$ & $22.32 \pm 0.49^{\mathrm{a}}$ & $22.88 \pm 0.80^{\mathrm{a}}$ & $18.12 \pm 1.27^{\mathrm{b}}$ \\
\hline Bacteria $\left(10^{7} \mathrm{~g}^{-1}\right)$ & $22.55 \pm 1.31^{\mathrm{b}}$ & $33.52 \pm 1.58^{\mathrm{a}}$ & $36.91 \pm 4.06^{\mathrm{a}}$ & $24.95 \pm 1.72^{\mathrm{b}}$ \\
\hline Actinomyces $\left(10^{4} \mathrm{~g}^{-1}\right)$ & $25.23 \pm 0.58^{\mathrm{b}}$ & $37.63 \pm 0.80^{\mathrm{a}}$ & $42.59 \pm 3.30^{\mathrm{a}}$ & $28.24 \pm 2.15^{\mathrm{b}}$ \\
\hline Fungus $\left(10^{3} \mathrm{~g}^{-1}\right)$ & $2.59 \pm 0.23^{\mathrm{b}}$ & $4.88 \pm 0.17^{\mathrm{a}}$ & $5.93 \pm 0.42^{\mathrm{a}}$ & $3.25 \pm 0.69^{\mathrm{b}}$ \\
\hline Catalase $\left(\mathrm{mL} \mathrm{g}^{-1}\right)$ & $16.29 \pm 2.94^{\mathrm{c}}$ & $24.18 \pm 1.07^{\mathrm{ab}}$ & $25.99 \pm 0.70^{\mathrm{a}}$ & $19.18 \pm 0.08^{\mathrm{bc}}$ \\
\hline Dehydrogenase $\left(\mu \mathrm{gg}^{-1}\right)$ & $115.50 \pm 14.04^{\mathrm{c}}$ & $195.99 \pm 3.96^{\mathrm{ab}}$ & $212.38 \pm 9.47^{\mathrm{a}}$ & $169.52 \pm 6.18^{b}$ \\
\hline Urease $\left(\mathrm{mg} \mathrm{g}^{-1}\right)$ & $0.14 \pm 0.02^{\mathrm{b}}$ & $0.16 \pm 0.01^{\mathrm{ab}}$ & $0.20 \pm 0.01^{\mathrm{a}}$ & $0.12 \pm 0.02^{\mathrm{b}}$ \\
\hline Invertase $\left(\mathrm{mg} \mathrm{g}^{-1}\right)$ & $17.04 \pm 0.70^{\mathrm{ab}}$ & $17.57 \pm 0.68^{\mathrm{ab}}$ & $19.37 \pm 0.69^{\mathrm{a}}$ & $15.76 \pm 0.80^{\mathrm{b}}$ \\
\hline
\end{tabular}

Different small letters in the same row mean significant difference at 0.05 level.

TABLE 4: Characteristics of soil infiltration rate and water storage capacity.

\begin{tabular}{|c|c|c|c|c|c|c|c|}
\hline $\begin{array}{l}\text { Thinning } \\
\text { intensity }\end{array}$ & $\begin{array}{l}\text { Stand density } \\
\left(\text { trees } \mathrm{hm}^{-2}\right)\end{array}$ & $\begin{array}{l}\text { Soil layer } \\
(\mathrm{cm})\end{array}$ & $\begin{array}{l}\text { Initial infiltration } \\
\text { rate } \\
\left(\mathrm{mm} \mathrm{min}^{-1}\right)\end{array}$ & $\begin{array}{c}\text { Stable } \\
\text { infiltration rate } \\
\left(\mathrm{mm} \mathrm{min}^{-1}\right)\end{array}$ & $\begin{array}{c}\text { Average infiltration } \\
\text { rate } \\
\left(\mathrm{mm} \mathrm{min}^{-1}\right)\end{array}$ & $\begin{array}{l}\text { Maximal water } \\
\text { storage capacity } \\
\quad\left(\mathrm{t} \mathrm{hm}^{-2}\right)\end{array}$ & $\begin{array}{c}\text { Noncapillary water } \\
\text { storage capacity } \\
\left(\mathrm{t} \mathrm{hm}^{-2}\right)\end{array}$ \\
\hline \multirow{3}{*}{ CK } & \multirow{3}{*}{2100} & $0 \sim 20$ & $35.67 \pm 1.30^{\text {bd }}$ & $19.05 \pm 1.78^{\mathrm{cd}}$ & $29.12 \pm 2.49^{\text {bd }}$ & $1061.80 \pm 24.75^{\text {bd }}$ & $211.53 \pm 5.87^{\text {bd }}$ \\
\hline & & $20 \sim 40$ & $31.75 \pm 0.52^{\mathrm{ce}}$ & $10.99 \pm 1.73^{\text {be }}$ & $13.79 \pm 2.08^{\text {be }}$ & $980.93 \pm 4.85^{\text {be }}$ & $179.47 \pm 3.32^{\text {be }}$ \\
\hline & & $40 \sim 60$ & $24.43 \pm 0.45^{\mathrm{cf}}$ & $1.76 \pm 0.47^{\mathrm{bf}}$ & $4.76 \pm 0.69^{\mathrm{cf}}$ & $909.20 \pm 21.27^{\mathrm{bf}}$ & $117.13 \pm 10.55^{\mathrm{bf}}$ \\
\hline \multirow{3}{*}{$15 \%$} & \multirow{3}{*}{1800} & $0 \sim 20$ & $42.82 \pm 0.53^{\mathrm{ad}}$ & $29.73 \pm 1.16^{\text {bd }}$ & $40.67 \pm 3.01^{\text {ad }}$ & $1262.13 \pm 20.56^{\text {ad }}$ & $303.93 \pm 5.24^{\mathrm{ad}}$ \\
\hline & & $20 \sim 40$ & $34.82 \pm 0.54^{\text {abe }}$ & $21.20 \pm 1.75^{\mathrm{ae}}$ & $21.87 \pm 1.99^{\mathrm{ae}}$ & $1021.67 \pm 11.74^{\text {be }}$ & $197.67 \pm 1.92^{\text {be }}$ \\
\hline & & $40 \sim 60$ & $26.54 \pm 0.46^{\mathrm{bf}}$ & $3.50 \pm 0.46^{\mathrm{abf}}$ & $7.73 \pm 0.74^{\mathrm{abf}}$ & $938.20 \pm 9.37^{\mathrm{bf}}$ & $140.80 \pm 4.45^{\mathrm{abf}}$ \\
\hline \multirow{3}{*}{$30 \%$} & \multirow{3}{*}{1500} & $0 \sim 20$ & $44.38 \pm 0.70^{\text {ad }}$ & $38.37 \pm 3.04^{\mathrm{ad}}$ & $42.97 \pm 3.05^{\mathrm{ad}}$ & $1381.13 \pm 71.18^{\text {ad }}$ & $311.67 \pm 20.76^{\text {ad }}$ \\
\hline & & $20 \sim 40$ & $36.74 \pm 0.79^{\mathrm{ae}}$ & $21.95 \pm 1.81^{\mathrm{ae}}$ & $24.66 \pm 2.12^{\mathrm{ae}}$ & $1163.40 \pm 32.76^{\mathrm{ae}}$ & $224.47 \pm 12.64^{\mathrm{ae}}$ \\
\hline & & $40 \sim 60$ & $30.06 \pm 0.50^{\mathrm{af}}$ & $4.77 \pm 0.87^{\mathrm{af}}$ & $9.09 \pm 1.05^{\mathrm{af}}$ & $1002.07 \pm 12.63^{\mathrm{af}}$ & $146.07 \pm 6.19^{\mathrm{af}}$ \\
\hline \multirow{3}{*}{$60 \%$} & \multirow{3}{*}{900} & $0 \sim 20$ & $37.29 \pm 0.97^{\text {bd }}$ & $19.89 \pm 2.26^{\mathrm{cd}}$ & $28.06 \pm 2.97^{\mathrm{bd}}$ & $1116.87 \pm 32.30^{\mathrm{bd}}$ & $243.67 \pm 15.52^{\text {bd }}$ \\
\hline & & $20 \sim 40$ & $33.32 \pm 0.45^{\text {bce }}$ & $11.73 \pm 2.56^{\mathrm{be}}$ & $13.98 \pm 2.23^{\mathrm{be}}$ & $996.47 \pm 18.24^{\text {be }}$ & $180.60 \pm 8.30^{\text {be }}$ \\
\hline & & $40 \sim 60$ & $24.91 \pm 0.20^{\mathrm{cf}}$ & $2.30 \pm 0.57^{\mathrm{bf}}$ & $6.11 \pm 0.72^{\mathrm{bcf}}$ & $915.67 \pm 4.55^{\mathrm{bf}}$ & $119.20 \pm 5.06^{\mathrm{bf}}$ \\
\hline
\end{tabular}

Different small letters mean significant difference at 0.05 level; ${ }^{\text {abc }}$ mean difference among different densities of the same soil layer; ${ }^{\text {def }}$ mean difference among different soil layers of the same density.

degree (Figure 3). The soil maximal water storage capacity and noncapillary water storage capacity of different thinning intensities followed the same order of control (nonthinning): $<60 \%<15 \%<30 \%$. The soil maximal water storage capacity and noncapillary water storage capacity in thinning 30\% and $15 \%$ were significantly different $(P<0.05)$ from the control whereas in thinning $60 \%$ had no significant difference $(P>0.05)$ from the control. In contrast to the control, the soil maximal water storage capacity and noncapillary water storage capacity in thinning 30\% were, respectively, increased by $20.1 \%$ and $34.3 \%$ and in thinning $15 \%$ were, respectively, increased by $9.1 \%$ and $26.4 \%$. Besides, both the soil maximal water storage capacity and noncapillary water storage capacity decreased significantly $(P<0.01)$ with the soil depth addition and they were, respectively, in a range of
909.20 1381.13 $\mathrm{thm}^{-2}$ and $117.13 \sim 311.67 \mathrm{thm}^{-2}$ from three soil layers (Table 4).

3.4. Relationships among Soil Infiltration Rates, Water Storage Capacities, and Soil Properties under Different Thinning Intensities. The soil physicochemical and biological properties were closely related to the soil infiltration rate and water storage capacity (Table 5). The indexes of soil infiltration rate and water storage capacity were significantly negatively correlated with soil bulk density and significantly positively correlated with soil total porosity, noncapillary porosity, organic matter content, bacteria, actinomyces, fungus, catalase, dehydrogenase, and urease, while the correlation with natural soil water content and soil $\mathrm{pH}$ was not significant. 
TABLE 5: Correlation analysis among soil infiltration rates, water storage capacities, and soil properties.

\begin{tabular}{|c|c|c|c|c|c|}
\hline Soil factor & $\begin{array}{c}\text { Initial infiltration } \\
\text { rate }\end{array}$ & $\begin{array}{c}\text { Stable infiltration } \\
\text { rate }\end{array}$ & $\begin{array}{c}\text { Average infiltration } \\
\text { rate }\end{array}$ & $\begin{array}{l}\text { Maximal water } \\
\text { storage capacity }\end{array}$ & $\begin{array}{c}\text { Noncapillary water } \\
\text { storage capacity }\end{array}$ \\
\hline Bulk density & $-0.920^{* *}$ & $-0.893^{* *}$ & $-0.868^{* *}$ & $-0.962^{* *}$ & $-0.913^{* *}$ \\
\hline Total porosity & $0.931^{* *}$ & $0.896^{* *}$ & $0.881^{* *}$ & $1.000^{* *}$ & $0.857^{* *}$ \\
\hline Noncapillary porosity & $0.891^{* *}$ & $0.914^{* *}$ & $0.821^{* *}$ & $0.858^{* *}$ & $1.000^{* *}$ \\
\hline Natural water content & 0.355 & 0.253 & 0.168 & 0.291 & 0.398 \\
\hline $\mathrm{pH}$ & -0.227 & -0.271 & -0.159 & -0.201 & -0.314 \\
\hline Organic matter & $0.846^{* *}$ & $0.853^{* *}$ & $0.867^{* *}$ & $0.842^{* *}$ & $0.888^{* *}$ \\
\hline Bacteria & $0.880^{* *}$ & $0.813^{* *}$ & $0.825^{* *}$ & $0.816^{* *}$ & $0.685^{*}$ \\
\hline Actinomyces & $0.925^{* *}$ & $0.950^{* *}$ & $0.858^{* *}$ & $0.840^{* *}$ & $0.972^{* *}$ \\
\hline Fungus & $0.918^{* *}$ & $0.885^{* *}$ & $0.874^{* *}$ & $0.917^{* *}$ & $0.851^{* *}$ \\
\hline Catalase & $0.884^{* *}$ & $0.874^{* *}$ & $0.862^{* *}$ & $0.843^{* *}$ & $0.802^{* *}$ \\
\hline Dehydrogenase & $0.876^{* *}$ & $0.842^{* *}$ & $0.792^{* *}$ & $0.845^{* *}$ & $0.891^{* *}$ \\
\hline Urease & $0.728^{* *}$ & $0.756^{* *}$ & $0.691^{*}$ & $0.854^{* *}$ & $0.742^{* *}$ \\
\hline Invertase & $0.587^{*}$ & $0.672^{*}$ & 0.513 & $0.659^{*}$ & $0.728^{* *}$ \\
\hline
\end{tabular}

${ }^{*} P<0.05 ;{ }^{* *} P<0.01$.

\section{Discussion}

This paper mainly studied the thinning effects on soil infiltration rate and water storage capacity. We found that thinning operations had a significant influence on soil infiltration rate and water storage capacity of pine-oak mixed forest, similar to the observation by Olajuyigbe et al. [30]. These results demonstrate that thinning operation of $30 \%$ intensity could substantially improve soil infiltration rate and water storage capacity of pine-oak mixed forest (Figures 2 and 3). The soil infiltration rate and water storage capacity of medium density (1500 1800 trees $\mathrm{hm}^{-2}$ ) forest were significantly higher than those of higher density (2100 trees $\mathrm{hm}^{-2}$ ) forest and lower density ( 900 trees $\mathrm{hm}^{-2}$ ) forest because the forest of medium density is in a better condition of adequate water, nutrients, and small pressure intraspecific competition to improve the soil infiltration rate and water storage capacity. However, too high or low density would inhibit ecological functions of forest soil, which is similar to the finding of Zhang et al. [31]. Therefore, the soil infiltration rate and water storage capacity could be regulated by adjusting stand density in the forest management.

The thinning operations can influence environmental conditions in forestland such as light, temperature, and soil properties $[11,32]$. This study showed that the soil property changed dramatically after thinning (Table 3 ). We found that the soil property was closely related to soil infiltration rate and water storage capacity (Table 5). The soil bulk density was significantly negatively correlated with the soil infiltration rate and water storage capacity which indicates that soil with smaller bulk density has better infiltration rate and water storage capacity. This result is in substantial agreement with that of Bangita and Rao [33]. Some authors have suggested that the soil infiltration rate and water storage capacity are related to the soil texture, structure, porosity, and organic matter content $[5,34]$. We found that the soil infiltration rate and water storage capacity notably increased with the increase of soil total porosity, noncapillary porosity, and organic matter content. This finding is in accordance with previous report [35]. Gao et al. indicate that the natural soil water content is closely related to the soil infiltration rate and water storage capacity [36], but, in this study, we found that the soil infiltration rate and water storage capacity had no significant correlation with natural soil water content. The reason may be that the natural soil water content in this study area is lower than other areas; as a result, it has not shown the impacts on soil initial infiltration value and matric potential gradient volume. The soil biological activity had a significant influence on soil infiltration rate and water storage capacity, consistent with the finding by Rauch-Williams and Drewes [37].

The soil infiltration rate and water storage capacity caused significant difference among different soil layers (Table 4; Figure 2). They were significantly higher in the surface layer $(0 \sim 20 \mathrm{~cm})$ than in the deep layers $(20 \sim 40 \mathrm{~cm}$ and $40 \sim 60 \mathrm{~cm})$. This is because the surface soil is covered by litter with a large quantity of biological return, high organic matter content, rich nutrient, and water $[38,39]$. Besides, due to the influence of vegetation roots, the soil structure becomes loose and porous with more organic hydrocolloids, and it can conserve more soil water [40].

Actually, the soil infiltration and water storage capacity are complex hydrological processes. As the soil infiltration rate and water storage capacity are not only affected by the types and structure of the forest, but also closely related to the litter amount, root distribution, and surface runoff [5]. Additionally, the conclusion was preliminary since this study was only based on investigation results of middle-aged pineoak mixed forest. Thus, further study is needed on pine-oak mixed forest before making comprehensive conclusions. 


\section{Conclusions}

Pine-oak mixed forest is an important water conservation forest in Qinling Mountains. As for the forest with stand density higher than 2100 trees $\mathrm{hm}^{-2}$, selecting appropriate thinning intensity had an obvious effect on improvement of soil infiltration rate and water storage capacity. In this study, the soil infiltration rate and water storage capacity in thinning 30\% were the best, in thinning $15 \%$ were the second, and in thinning $60 \%$ were the worst. From these results, we conclude that thinning operation with $30 \%$ intensity is the optimal practice for improving the soil infiltration rate and water storage capacity of pine-oak mixed forest in Qinling Mountains of China.

\section{Conflict of Interests}

The authors declare that there is no conflict of interests regarding the publication of this paper.

\section{Acknowledgments}

The authors thank Chinese Qinling National Forest Ecosystem Research Station for their help in fieldwork. Thanks also are due to insight comments from anonymous reviewers to improve the paper. This work was jointly supported by the National Natural Science Foundation of China (31070570), National Forestry Project of Research Program (20100400206).

\section{References}

[1] P. Gourbesville, "Challenges for integrated water resources management," Physics and Chemistry of the Earth, vol. 33, no. 5, pp. 284-289, 2008.

[2] W. C. Sun, J. Wang, Z. J. Li, X. L. Yao, and J. S. Yu, "influences of climate change on water resources availability in Jinjiang Basin, China," The Scientific World Journal, vol. 2014, Article ID 908349, 7 pages, 2014.

[3] Y. Nakagawa and G. Iwatsubo, "Water chemistry in a number of mountainous streams of east Asia," Journal of Hydrology, vol. 240, no. 1, pp. 118-130, 2000.

[4] B. Zhang, W. H. Li, G. D. Xie, and Y. Xiao, "Water conservation of forest ecosystem in Beijing and its value," Ecological Economics, vol. 69, no. 7, pp. 1416-1426, 2010.

[5] O. Bens, N. A. Wahl, H. Fischer, and R. F. Hüttl, "Water infiltration and hydraulic conductivity in sandy cambisols: impacts of forest transformation on soil hydrological properties," European Journal of Forest Research, vol. 126, no. 1, pp. 101-109, 2007.

[6] J. Leonard and P. Andrieux, "Infiltration characteristics of soils in Mediterranean vineyards in Southern France," Catena, vol. 32, no. 3-4, pp. 209-223, 1998.

[7] J. M. Warren, F. C. Meinzer, J. R. Brooks, and J. C. Domec, "Vertical stratification of soil water storage and release dynamics in Pacific Northwest coniferous forests," Agricultural and Forest Meteorology, vol. 130, no. 1-2, pp. 39-58, 2005.

[8] J. W. Zhou, C. Shi, and F. G. Xu, "Geotechnical characteristics and stability analysis of rock-soil aggregate slope at the Gushui Hydropower Station, southwest China," The Scientific World Journal, vol. 2013, Article ID 540636, 16 pages, 2013.
[9] X. Q. Liu, Z. W. Zhang, B. G. Shen, and Y. P. Wang, "Estimation of economic values of water conservation function by forest in Qinling national ecology function zone," Bulletin of Soil and Water Conservation, vol. 32, no. 1, pp. 177-180, 2012 (Chinese).

[10] T. Nishizono, K. Tanaka, K. Hosoda, Y. Awaya, and Y. Oishi, "Effects of thinning and site productivity on culmination of stand growth: results from long-term monitoring experiments in Japanese cedar (Cryptomeria japonica D. Don) forests in northeastern Japan," Journal of Forest Research, vol. 13, no. 5, pp. 264-274, 2008.

[11] R. Picchio, F. Neri, E. Petrini, S. Verani, E. Marchi, and G. Certini, "Machinery-induced soil compaction in thinning two pine stands in central Italy," Forest Ecology and Management, vol. 285, no. 8, pp. 38-43, 2012.

[12] S. M. Jackson, T. S. Fredericksen, and J. R. Malcolm, "Area disturbed and residual stand damage following logging in a Bolivian tropical forest," Forest Ecology and Management, vol. 166, no. 1, pp. 271-283, 2002.

[13] H. M. Wang, W. Liu, W. J. Wang, and Y. G. Zu, "Influence of long-term thinning on the biomass carbon and soil respiration in a larch (Larix gmelinii) forest in Northeastern China," The Scientific World Journal, vol. 2013, Article ID 865645, 9 pages, 2013.

[14] X. R. Cheng, M. K. Yu, and T. G. Wu, "Effect of forest structural change on carbon storage in a coastal Metasequoia glyptostroboides stand," The Scientific World Journal, vol. 2013, Article ID 830509, 9 pages, 2013.

[15] T. Nishizono, "Effects of thinning level and site productivity on age-related changes in stand volume growth can be explained by a single rescaled growth curve," Forest Ecology and Management, vol. 259, no. 12, pp. 2276-2291, 2010.

[16] S. D. Roberts and C. A. Harrington, "Individual tree growth response to variable-density thinning in coastal Pacific Northwest forests," Forest Ecology and Management, vol. 255, no. 7, pp. 2771-2781, 2008.

[17] L. H. Bach, J. Grytnes, R. Halvorsen, and M. Ohlson, "Tree influence on soil microbial community structure," Soil Biology and Biolinebreak chemistry, vol. 42, no. 11, pp. 1934-1943, 2010.

[18] R. E. J. Boerner, T. A. Waldrop, and V. B. Shelburne, "Wildfire mitigation strategies affect soil enzyme activity and soil organic carbon in loblolly pine (Pinus taeda) forests," Canadian Journal of Forest Research, vol. 36, no. 12, pp. 3148-3154, 2006.

[19] Y. Q. Geng, J. Dighton, and D. Gray, "The effects of thinning and soil disturbance on enzyme activities under pitch pine soil in New Jersey Pinelands," Applied Soil Ecology, vol. 62, no. 1, pp. $1-7,2012$.

[20] S. Maassen, H. Fritze, and S. Wirth, "Response of soil microbial biomass, activities, and community structure at a pine stand in northeastern Germany 5 years after thinning," Canadian Journal of Forest Research, vol. 36, no. 6, pp. 1427-1434, 2006.

[21] C. L. Woodward, "Soil compaction and topsoil removal effects on soil properties and seedling growth in Amazonian Ecuador," Forest Ecology and Management, vol. 82, no. 1-3, pp. 197-209, 1996.

[22] K. A. Smith and C. E. Mullins, Soil Analysis: Physical Methods, CRC Press, Marcel Dekker, New York, NY, USA, 1991.

[23] Y. H. Sun, H. J. Zhang, J. H. Cheng, Y. J. Wang, J. Shi, and Y. Cheng, "Soil characteristics and water conservation of different forest types in Jinyun Mountain," Journal of Soil and Water Conservation, vol. 20, no. 2, pp. 106-109, 2006 (Chinese).

[24] D. W. Nelson and L. E. Sommers, "Total carbon, organic carbon and organic matter," in Methods of Soil Analysis, Part 2, A. L. 
Page, R. H. Miller, and D. R. Keeney, Eds., pp. 574-577, Soil Science Society of America, Madison, Wis, USA, 1982.

[25] R. P. Larkin, "Characterization of soil microbial communities under different potato cropping systems by microbial population dynamics, substrate utilization, and fatty acid profiles," Soil Biology and Biochemistry, vol. 35, no. 11, pp. 1451-1466, 2003.

[26] J. L. Johnson and K. L. Temple, "Some variables affecting the measurement of catalase activity in soil," in Soil Science Society of America Journal, vol. 28, pp. 207-209, 1964.

[27] R. Margesin, A. Zimmerbauer, and F. Schinner, "Monitoring of bioremediation by soil biological activities," Chemosphere, vol. 40, no. 4, pp. 339-346, 2000.

[28] P. Nannipieri, B. Ceccanti, S. Cervelli, and E. Matarrese, "Extraction of phosphatase, urease, protease, organic carbon and nitrogen from soil," in Soil Science Society of America Journal, vol. 44, pp. 1011-1016, 1980.

[29] W. T. Frankeberger and J. B. Johanson, "Method of measuring invertase activity in soils," Plant and Soil, vol. 74, no. 3, pp. 301311, 1983.

[30] S. Olajuyigbe, B. Tobin, M. Saunders, and M. Nieuwenhuis, "Forest thinning and soil respiration in a Sitka spruce forest in Ireland," Agricultural and Forest Meteorology, vol. 157, pp. 86-95, 2012.

[31] J. Zhang, W. W. Oliver, and M. W. Ritchie, "Effect of stand densities on stand dynamics in white fir (Abies concolor) forests in northeast California, USA," Forest Ecology and Management, vol. 244, no. 36, pp. 50-59, 2007.

[32] P. N. J. Lane and S. M. Mackay, "Streamflow response of mixed-species eucalypt forests to patch cutting and thinning treatments," Forest Ecology and Management, vol. 143, no. 1, pp. 131-142, 2001.

[33] B. Bangita and B. K. R. Rao, "Impacts of compaction relief treatments on soil physical properties and performance of sugarcane (Saccharum spp.) under zonal tillage system," Geoderma, vol. 189-190, no. 2, pp. 351-356, 2012.

[34] J. Neris, C. Jiménez, J. Fuentes, G. Morillas, and M. Tejedor, "Vegetation and land-use effects on soil properties and water infiltration of Andisols in Tenerife (Canary Islands, Spain)," Catena, vol. 98, no. 6, pp. 55-62, 2012.

[35] A. J. Franzluebbers, "Water infiltration and soil structure related to organic matter and its stratification with depth," Soil and Tillage Research, vol. 66, no. 2, pp. 197-205, 2002.

[36] Y. P. Gao, T. N. Zhao, H. Luo, L. Chen, Y. Han, and Z. H. Wang, "Soil Hydro-physical properties of artificial robinia pseudoacacia forests in loess hilly-gully region," Journal of Northeast Forestry University, vol. 39, no. 2, pp. 64-71, 2011 (Chinese).

[37] T. Rauch-Williams and J. E. Drewes, "Using soil biomass as an indicator for the biological removal of effluent-derived organic carbon during soil infiltration," Water Research, vol. 40, no. 5, pp. 961-968, 2006.

[38] B. Berg, "Litter decomposition and organic matter turnover in northern forest soils," Forest Ecology and Management, vol. 133, no. 1-2, pp. 13-22, 2000.

[39] Z. Koukoura, A. P. Mamolos, and K. L. Kalburtji, "Decomposition of dominant plant species litter in a semi-arid grassland," Applied Soil Ecology, vol. 23, no. 1, pp. 13-23, 2003.

[40] A. Albrecht, U. Schultze, M. Liedgens, H. Flühler, and E. Frossard, "Incorporating soil structure and root distribution into plant uptake models for radionuclides: toward a more physically based transfer model," Journal of Environmental Radioactivity, vol. 59, no. 3, pp. 329-350, 2002. 

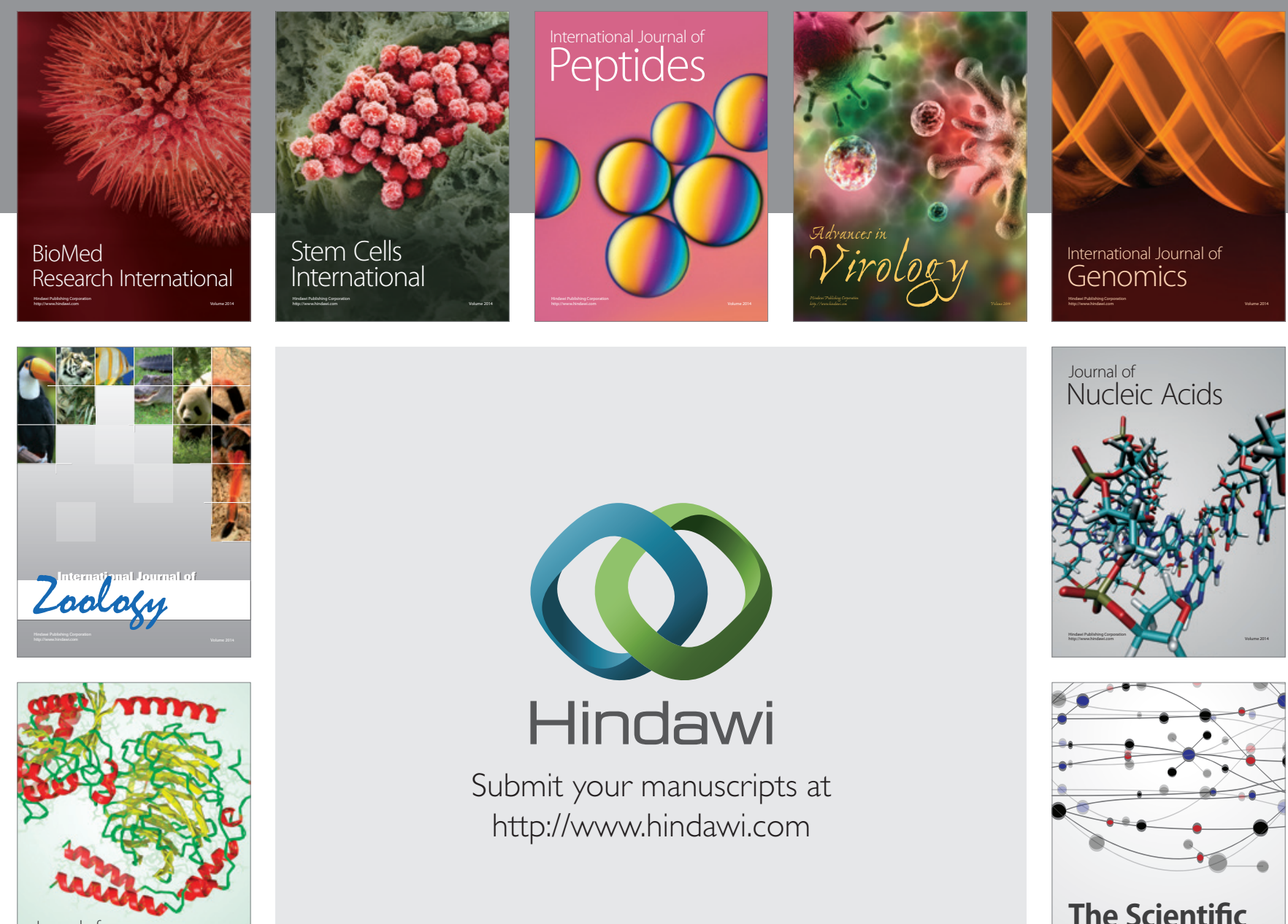

Submit your manuscripts at

http://www.hindawi.com

Journal of
Signal Transduction
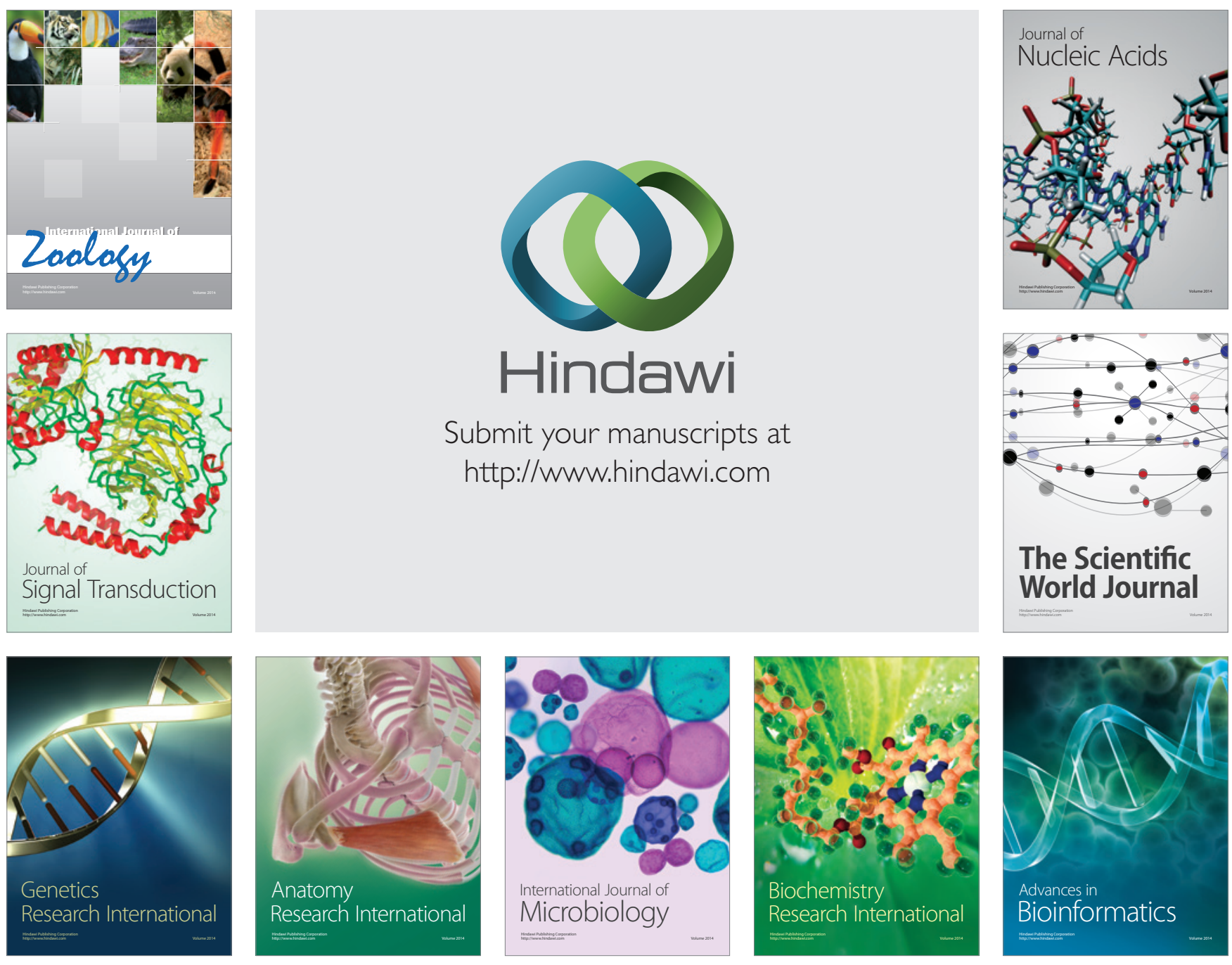

The Scientific World Journal
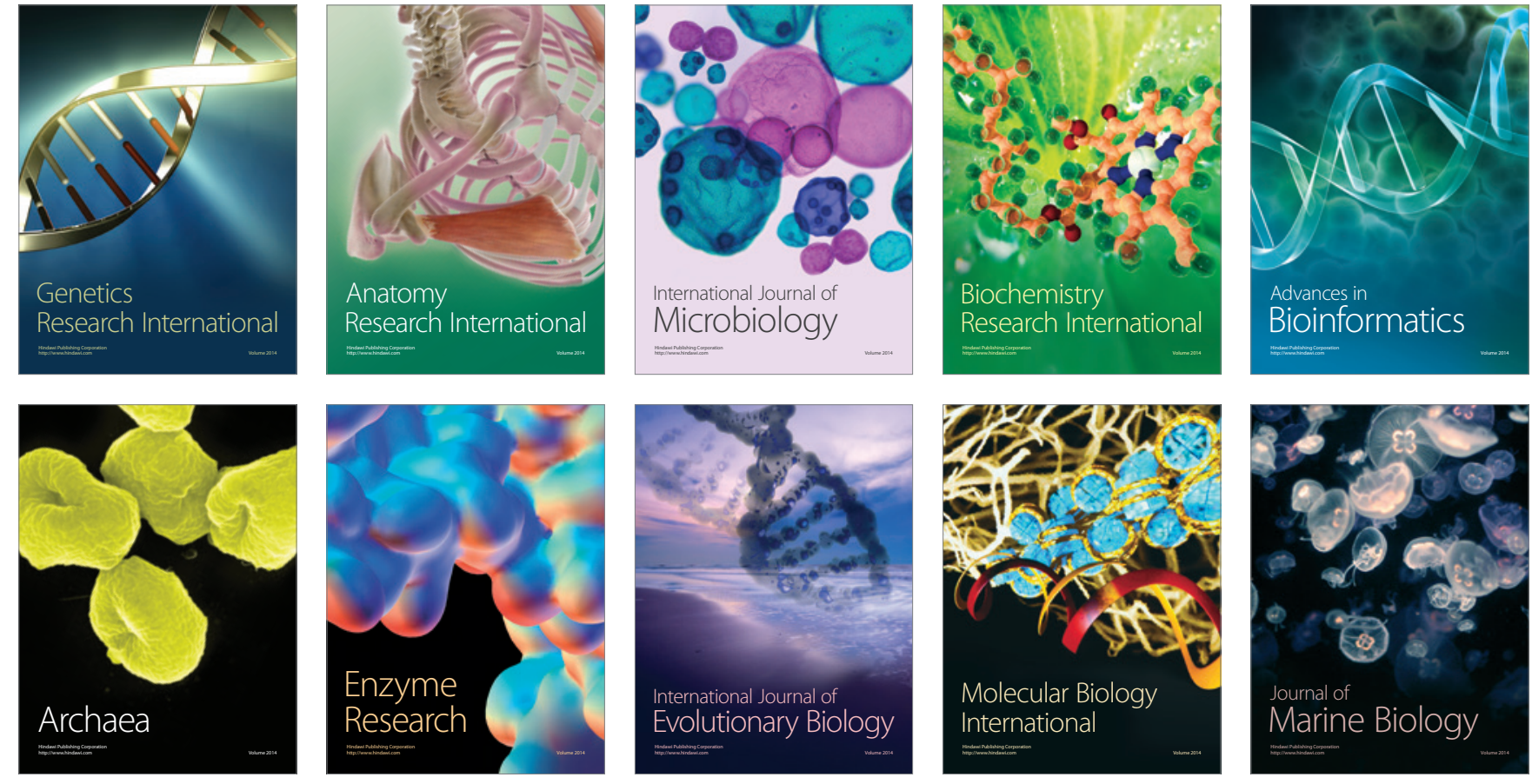